Contested Rituals 



\section{Contested Rituals}

Circumcision, Kosher Butchering, and Jewish Political Life in Germany, 1843-1933

$+t+t+t+t+t+t+\dagger$

ROBIN JUDD

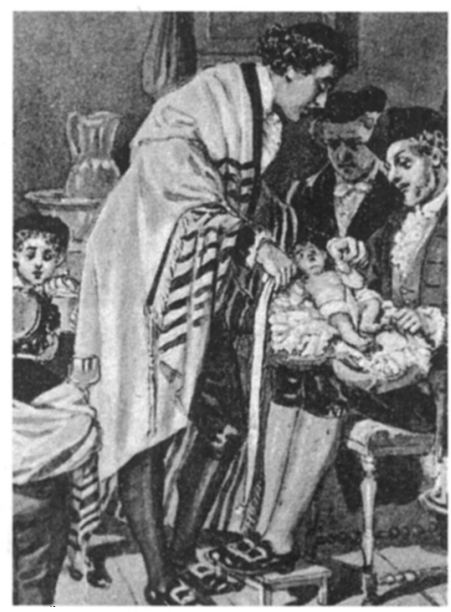

CORNELL UNIVERSITY PRESS Ithaca and London 


\section{Copyright $\odot 2007$ by Cornell University}

All rights reserved. Except for brief quotations in a review, this book, or parts thereof, must not be reproduced in any form without permission in writing from the publisher. For information, address Cornell University Press, Sage House, 512 East State Street, Ithaca, New York 14850.

First published 2007 by Cornell University Press

Printed in the United States of America

Library of Congress Cataloging-in-Publication Data

Judd, Robin.

Contested rituals : circumcision, kosher butchering, and Jewish political life in Germany, 1843-1933 / Robin Judd.

p. $\mathrm{cm}$.

Includes bibliographical references and index.

ISBN 978-0-8014-4545-3 (cloth : alk. paper)

1. Jews-Germany-History-1800-1933. 2. Judaism-GermanyCustoms and practices. 3. Circumcision-Religious aspects-Judaism. 4. Shehitah. I. Title.

DS134.25.J83 2007

305.892'404309034-dc22

2007010666

Cornell University Press strives to use environmentally responsible suppliers and materials to the fullest extent possible in the publishing of its books. Such materials include vegetable-based, low-VOC inks and acid-free papers that are recycled, totally chlorine-free, or partly composed of nonwood fibers. For further information, visit our website at www.cornellpress.cornell.edu.

Cloth printing 10987654321 
For My Parents 
